\title{
Assesing Home Port Potential of Selected Adriatic Ports
}

\author{
Marina Zanne, Bojan Beškovnik
}

The cruise industry has been continuously growing since the 1970s and is considered to be the fastest growing travel vacation segment ever. The Mediterranean is currently the second most visited region, closely following the Caribbean. One of the Mediterranean cruise markets is the increasingly interesting Adriatic Sea, with Venice and Dubrovnik as the most popular destinations. While a port of call destination need only offer attractions to be added to cruise line itineraries, much more is required of home ports, particularly in terms of infrastructure and passenger services.

Currently, the ports of Venice and Bari act as main home ports in the Adriatic, with the port of Trieste growing in importance although it does not as yet have a considerable share in terms of number of exchanged cruise passengers. In this paper, the authors take a look at the advantages that these ports offer in terms of home port adequacy and examine the home port potential of two Adriatic ports, namely the port of Koper and the port of Split. For this purpose, a list of influencing factors was drawn up based on existing studies and adjusted to the specific micro conditions and requirements. These factors are examined.

\section{KEY WORDS}

$\sim$ Cruise shipping

$\sim$ Home port

$\sim$ Adriatic region

$\sim$ Influencing factors

$\sim$ Survey

University of Ljubljana, Faculty of Maritime Studies and Transport, Slovenia

e-mail: marina.zanne@fpp.uni-lj.si

doi: 10.7225/toms.v07.n02.004

This work is licensed under (cc) BY

\section{INTRODUCTION}

Sea cruising dates back to the nineteenth century when liner companies with spare passenger ships started to offer occasional cruising (Stopford, 2009) and almost everyone agrees that the first travel agent was Thomas Cook, who organized his first Grand Tour of Europe in 1856 (Dickinson and Vladimir, 2008). However, until the 1960s and the tourist boom of the Caribbean market in which cruises now account for more than $50 \%$ of all tourist arrivals (Brida and Zapata, 2010) the cruising market was mostly limited to rich people. Thereafter, the cruise industry has become the fastest-growing and most rapidly emerging category in the leisure travel market (CLIA, 2017; Dickinson and Vladimir, 2008; Dowling, 2006); in fact it realized a 2,100\% growth since the 1970s (Repositioning Cruises, 2014). The industry continued to grow and a record was broken in 2016 with 24.2 million passengers cruising globally, i.e. $4 \%$ more than in 2015, with estimated 25.3 million passengers anticipated in 2017 (FCCA, 2017). Although still a relatively small segment of the tourist industry, the cruise industry is certainly an important one; in 2015 the total economic impact of the global cruise industry was the generation of US\$117 billion and opening of almost 957 thousand jobs, paying US\$38 billion in wages and salaries (FCCA, 2017). However, cruise ships are simultaneously one of the most energy intense forms of tourist activity (Eijgelaar, Thaper and Peeters, 2010). This is due to the fact that cruise ships are essentially treated as big, luxury hotels throughout their journeys and emit huge amount of emissions while in port. In addition, cruise ships are tremendous generators of wastewater proven to have negative impact on the marine environment (Perić, 2016).

Nevertheless, the growth of the cruising industry may be attributed to the increasing number of users and the growing 
number of destinations. The cruising industry still has the potential for growth in both respects; people who take cruises are very loyal to cruising, with approx. $92 \%$ stating they will probably or definitively book a cruise for a next vacation. In addition, younger generations are embracing cruise travel, rating it as a better vacation type than land-based vacations, all-inclusive resorts, tours, vacation house rentals, or camping (CLIA, 2017).

Driven by high occupancy rates and positive forecasts, cruise companies continue to expand their fleets; the current fleet of approximately 330 seagoing cruise vessels is to be expanded by sixteen new cruise ships, having the total capacity of more than 34,000 lower berths ${ }^{1}$, in 2018 alone, with additional 77 ships with the capacity of approximately 223,500 lower berths already planned for delivery by 2027 (based on CIN (2018)).
Cruise shipping is a profitable sector significantly contributing to economies of the countries involved, although cruise passengers seem to daily spend less than $30 \%$ of the expenditure of a land tourist (Brida and Zapata, 2010). Home port of course brings more money to the region, as the cruise tourists often spend some time before or after the cruise voyage in the city or its surroundings.

Currently, the global cruise port system is characterized by a high level of regional concentration and a clustering of port visits (Rodrigue and Notteboom, 2013) as illustrated in Figure 1 , although apart from new destinations in established cruise regions, some new cruise markets are emerging, especially in Asia.

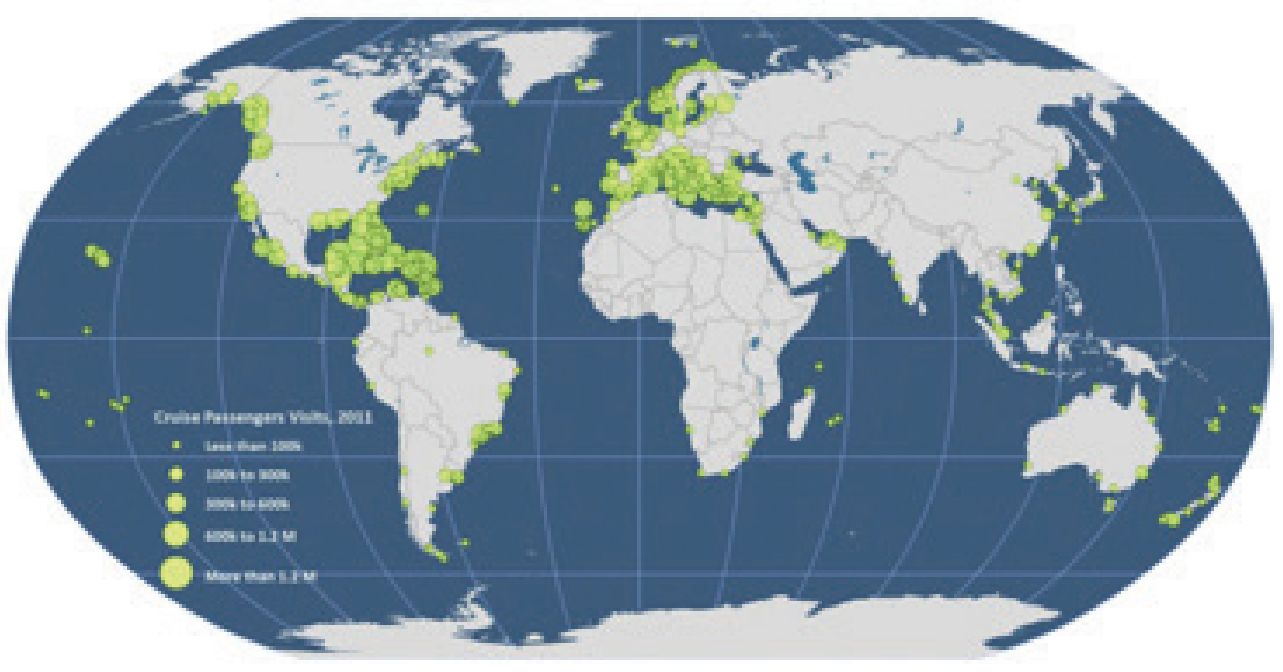

Figure 1.

The concentration of cruise markets (Source: Rodrigue \& Notteboom, 2013).

The promotion of destinations and gaining of customers usually take place on fairs. In order for a shipping company to choose a port as a home port, the port must meet a number of criteria that are not dependent on the port itself or the attractiveness of the destination alone.

In this paper, the author analyses cruise traffic in the Adriatic, with particular attention given to the port of Koper and the port of Split. The main objective of the paper is to determine their growing potential and examine their home port potential.

1. Used to measure the normal capacity of a ship when two beds in each cabin are occupied.

\section{THEORETICAL BACKGROUND}

Cruise ports are generally divided into three categories, namely home ports, ports of call (also known as transit ports or destination ports) and hybrid ports. Home ports are ports where cruises begin and end, ports of call are intermediate stoppages and hybrid ports are the mixture of the previous two categories (Lakakou, Pallis and Vaggelas, 2009). In addition, some cruise companies allow boarding at a specific port as a part of a scheduled itinerary and disembarkation at the same port during the ship's next scheduled itinerary, in effect allowing passengers to do only a part of two regular cruises (Celebrity Cruises, 2018). This port is called an interport and the activity is known as interport sailing or interporting in which other than a regular 
home port for a line actually acts as a home port for a part of the passengers. Interporting thus simply means the creation of a secondary embarkation and disembarkation port on a cruise line. European cruise companies, such as MSC and Costa, have been doing this for years. This allows passengers to take the ship from their home city, or one that is closer to home, saving transportation and hotel costs (or the cost associated with flying to a particular city), and provides the line with new revenues. It also allows a passenger to pick a destination of more pre- and post-cruise interest (Reimer, 2012).

The direct economic benefits of cruise tourism for each destination arise from three principal sources (BREA, 2015):

- passenger onshore expenditures concentrated in shore excursions and retail purchases of clothing and jewelry;

- $\quad$ onshore spending by crew concentrated in purchases of food and beverages, local transportation and retail purchases of clothing and electronics; and

- $\quad$ expenditures by the cruise lines for supplies, such as food and beverages, port services, such as navigation and utility services, and port fees and taxes such as wharfage and dockage fees.

In average, passengers spend around EUR 95, and crew members EUR 25 per day in ports in EU countries with cruise tourism (EC, 2009). The latest available data for Europe show that each EUR 1 million in direct cruise industry expenditures generated EUR 2.42 million in business output and 19 jobs with an average annual wage of nearly EUR 33,700 (CLIA Europe, 2015).

According to Lakakou et al. (2009) a cruise port is generally interested in becoming a home port for one or more cruise companies. This is due to the high economic impact of this development on the port and the port related city. In fact, cruise passengers are estimated to spend six to seven times more money in home ports than at ports of call (CLIA Europe, 2007).

While minimum requirements for ports of call are clean and safe quay/pier/berthing, safe anchorage/tender spot (SeaConsult, 2012) and maybe simple check procedures, the list of requirements for cruise home ports is much more extensive. There are not many studies available on cruise home port selection criteria. Lakakou et al. (2009), Castillo-Manzano et al. (2014), Pallis (2015) and more recently Meng-Zhi et al. (2018) have been dealing with home port selection criteria and their prioritization. Castillo-Manzano et al. (2014) have created regression models on selected Spanish ports and found that ports located in populous areas with ample accommodation facilities, in the vicinity of large airports, not specialized in container traffic but sharing facilities with ferry traffic are more likely to attract cruise traffic. Lakakou et al. (2009) on the other hand drew up a list of 81 cruise home port selection criteria, and divided them into 12 categories and further into two groups, namely site characteristics and situation characteristics. They created a questionnaire and distributed it to 21 expert entities, including cruise companies, agents, cruise brokers, port authorities etc. to identify the most important factors. Among those 81 criteria, 31 have scored more than 4 points on the Likert scale, among which the availability of wellconnected international airport with adequate capacity is the most important. Despite the case-by-case approach to home port selection, there are some major conditions that a cruise port itself must fulfil in order to become a home port. Pallis (2015) summarized them from Lakakou et al. (2009) as follows:

- the presence of adequate port infrastructure;

- the efficient provision of an extensive range of services to the cruise ship, the passengers and the crew; and

- connectivity with other transport modes.

Since international shipping always seeks a hospitable economic and political climate from which to operate, to keep costs competitive, cruise ships operators on occasion move from country to country, i.e. they switch from one home port to another (Klein, 2002). This means that ports face the constant risk of losing clients, not because of deficiencies in port infrastructure or terminal operations, but because the client has new and different requirements (Zarei, 2015).

\section{DATA AND METHODS}

Publically available quantitative data and data obtained through participation in the European strategic projectEA SeaWay were used in the paper. The accuracy of publically available data is limited, e.g. the same publication may contain data for the same issue that are at odds with each other. In general, MedCruise data suggest a smaller number of passengers in the analysed regions since not all ports are included in the programme, but these data can still be used to get a general picture.

Five ports were included in the analysis - Venice, Bari and Trieste as existing home ports in the Adriatic, and Koper and Split as potential home ports. The analysed data cover a ten-year period from 2007 to 2016. The first cruise ship called to Split in 2002 and to Koper in 2005. The annual growth was expectedly enormous in these starting years (e.g. a 1,485\% growth in Koper in 2007) and if included in the analysis they would yield rather misleading results.

Quantitative and qualitative analysis have been performed. Descriptive statistics were used to get a general picture of the performance of selected ports and several computations allowed the identification of trends. Based on the existing studies and using a multi-aspect approach a list of 14 criteria for home port selection was created. These criteria have been further examined for the selected five ports. For each of the analysed ports the main positive or negative issues have been identified and are presented further in the paper. 


\section{THE ANALYSIS}

The cruise product has become highly diversified and cruise companies develop new itineraries, new concepts and vessels for all kind of tastes (Papadopoulou and Sambracos, 2014) in order to attract more passengers and achieve even better financial results.

\subsection{Cruise shipping in the Adriatic Sea}

Around 6.59 million passengers were cruising European waters in 2015, accounting for 43.94 passenger and crew visit days at ports (BREA, 2016). In the same year, the cruise industry's total economic output in Europe reached EUR 40.95 billion, including EUR 16.89 billion in direct spending by cruise lines. It also accounted for more than 360,000 European jobs, generating more than EUR 11 billion in terms of employee compensation (CLIA Europe, 2015).

The Mediterranean area is the most attractive cruising zone in Europe (it is included in 75\% of Europe's itineraries and is the fastest growing cruise destination in Europe (Papadopoulou \& Sambracos, 2014)), and the world's second most popular cruising destination, closely following the Caribbean region. These two markets are complementary in the sense that the Caribbean region is dominantly serviced during the winter while the Mediterranean experiences a summer peak season (Rodrigue and Notteboom, 2012), so they are not in directly competing position, but are instead interconnected in an operational manner, particularly through the repositioning of vessel units to cope with variations in seasonal demand among the regional markets (Rodrigue and Notteboom, 2013). But with respect to passengers, in most cases they offer different attractions; while the growing popularity of exotic and resort destinations is noted in the Caribbean region, in the Mediterranean, the accent is on cultural attractions in close proximity to ports. The demand for different regions is thus mainly based on passenger preferences.

The Mediterranean region is divided into four sub regions; among which the Adriatic is the second most visited, only falling behind the Western Mediterranean.

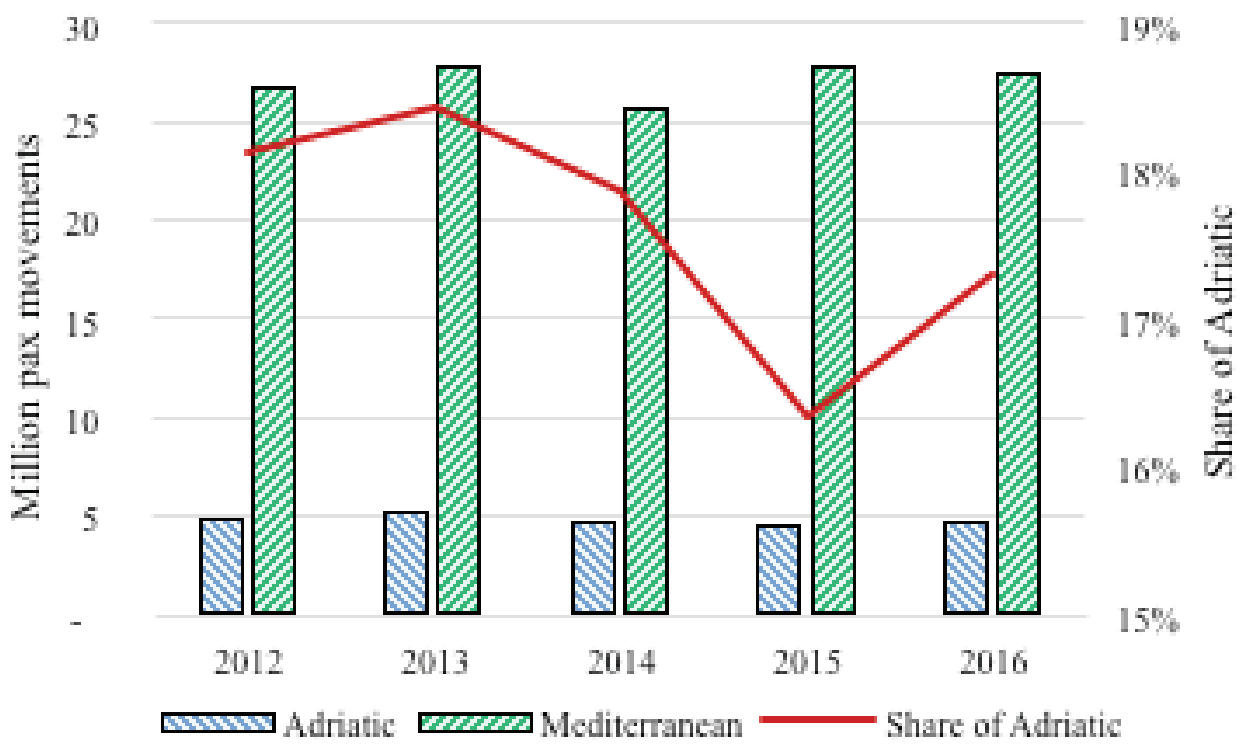

Figure 2.

Adriatic and Mediterranean pax movements. Source: (Risposte turismo, 2017).

When peace was restored in the Adriatic region in the mid 1990s, interesting new ports in Croatia were added to Mediterranean cruise itineraries which traditionally focused on Italy, Greece and Spain (Selinsky, 2010). The Adriatic region has a relatively steady number of passenger movements - around 5 million per season in the last decade.
Since the early 2000s, the number of ports of call has considerably increased in the Mediterranean Sea (Papadopoulou and Sambracos, 2014), and the Adriatic is not an exception. Currently around 30 cruise ports are in use by cruise lines in the Adriatic Sea. This is in line with the results of a survey which found that the diversification of ports of call and the attractions within 
the various ports were key factors for an itinerary to be successful and profitable (Tsamboulas, Moraiti and Koulopoulou, 2013).

As we can see in Figure 3, the port of Koper and the port of Split are both ranked among 10 top cruise ports in the Adriatic; however in 2016 their cumulative share in terms of passenger movements was barely $7 \%$. In fact, the majority of Adriatic cruise ports are small ports as the four most important ports cumulatively registered almost $75 \%$ of all passengers' visits in 2016.

Cruise traffic in the Adriatic is present throughout the year, with the peak period from May to October accounting for more than $85 \%$ (Risposte turismo, 2017), which is causing problems in many ports and port cities.
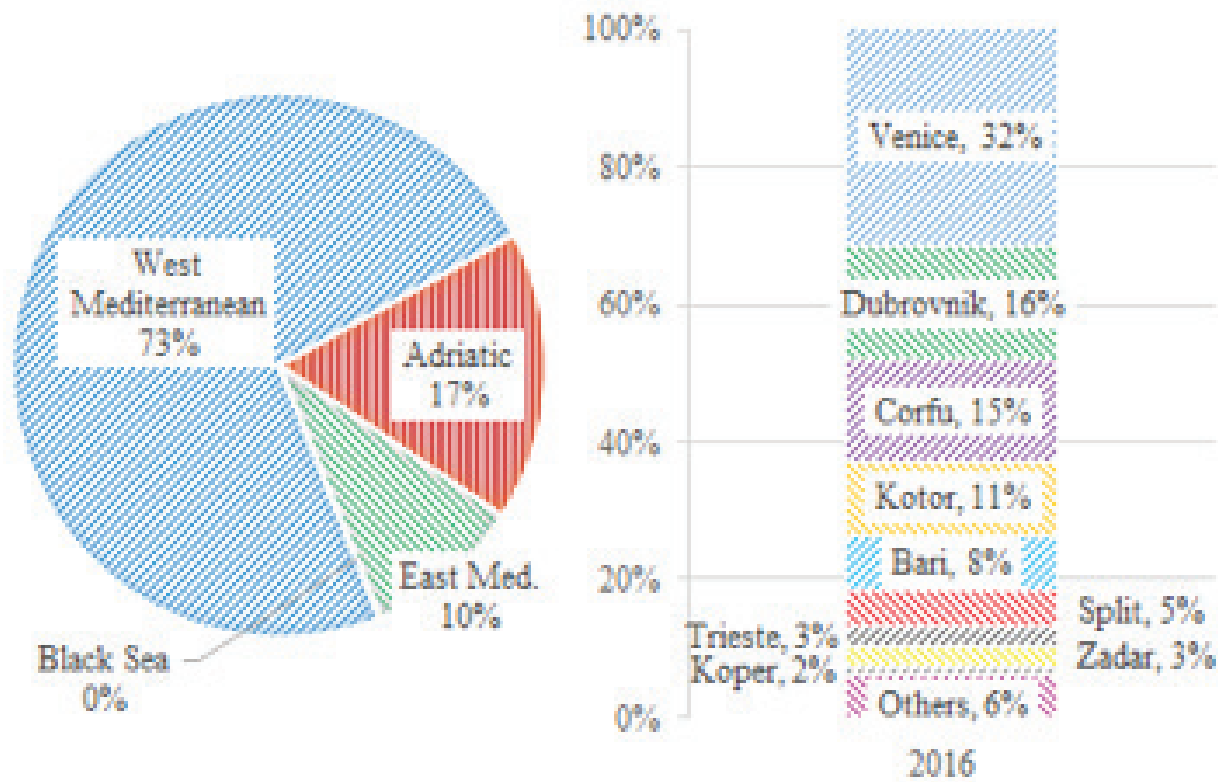

Figure 3.

Cruise passenger break down for the Adriatic. Source: based on (Risposte turismo, 2017).

\subsection{Home port selection criteria}

Based on the study by Lakakou et al. (2009) and the conclusions of Pallis (2015), using a multi-aspect approach for home port selection, we analysed the following criteria:

(1) the vicinity of an international airport;

(2) airport connections (regular lines);

(3) airport capacity / number of passengers;

(4) capacity for handling a large number of passengers simultaneously;

(5) infrastructure for passenger embarkation and disembarkation / baggage handling

(6) passenger services (duty free, food and beverage area, information desk);

(7) capacity (length of berths);

(8) passenger terminals / number of berths;

(9) tourist attractions (historic, cultural, entertainment); (10)check-in desks / check-in desks for reduced mobility passengers / security screening lines;

(11)cost of services to cruise ships;

(12)services for ships;

(13)cost of services to passengers;

(14)(secured) parking.

Home ports in the Adriatic and home port potential of the ports of Koper and Split

The Adriatic is mainly characterized by transit cruise traffic although Venice, Bari and, more recently Trieste, account for a considerable share of embarkations and disembarkations in the total number of passenger movements.

Figure 5 illustrates the market position of the selected ports - three current rather important Adriatic home ports and two ports analysed to identify their home port potential. Expectedly, smaller ports have higher CAGR. 


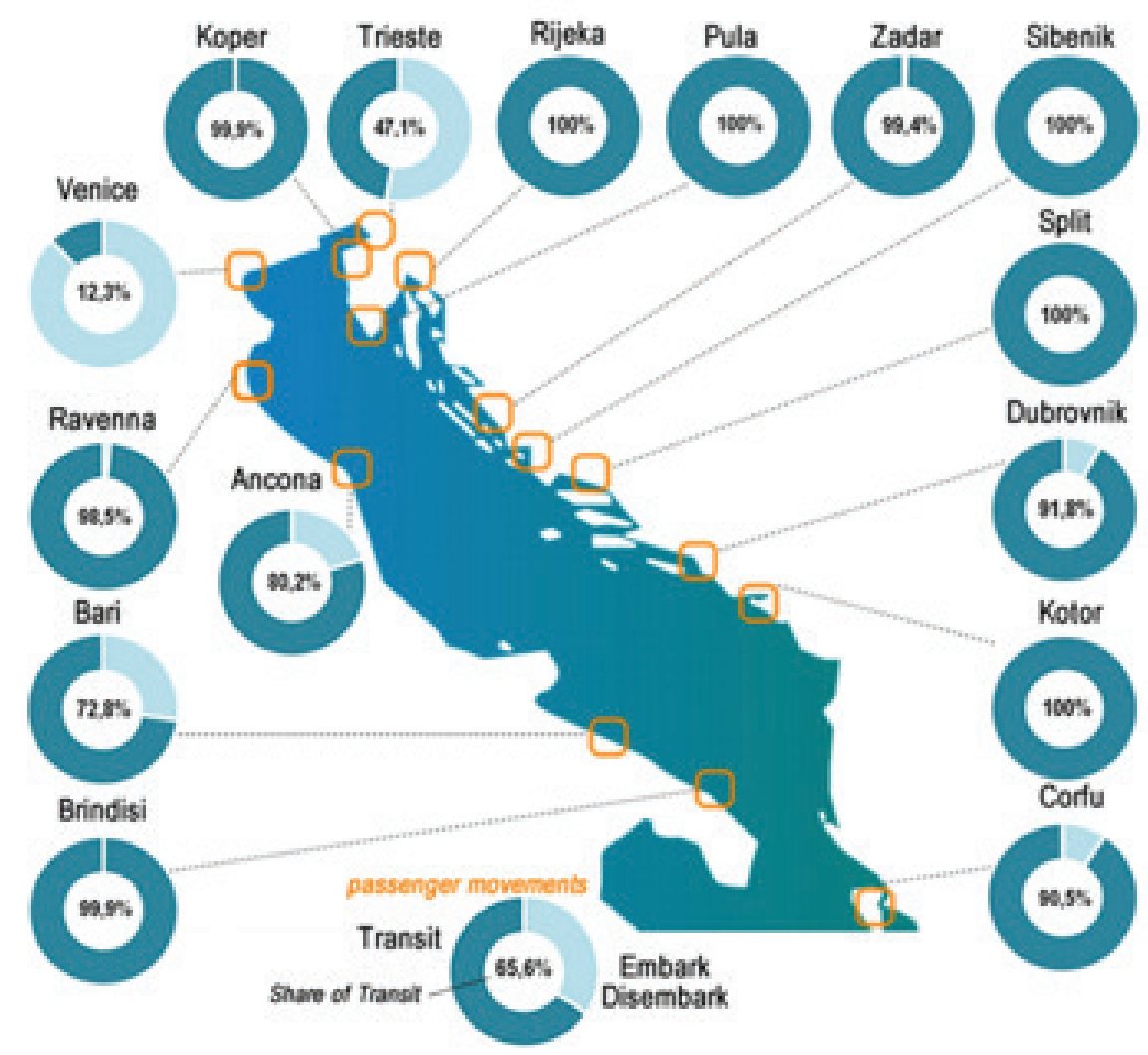

Figure 4.

Percentage distribution of cruise traffic between embarkations-disembarkations and transits, 2016. Source: (Risposte turismo, 2017).

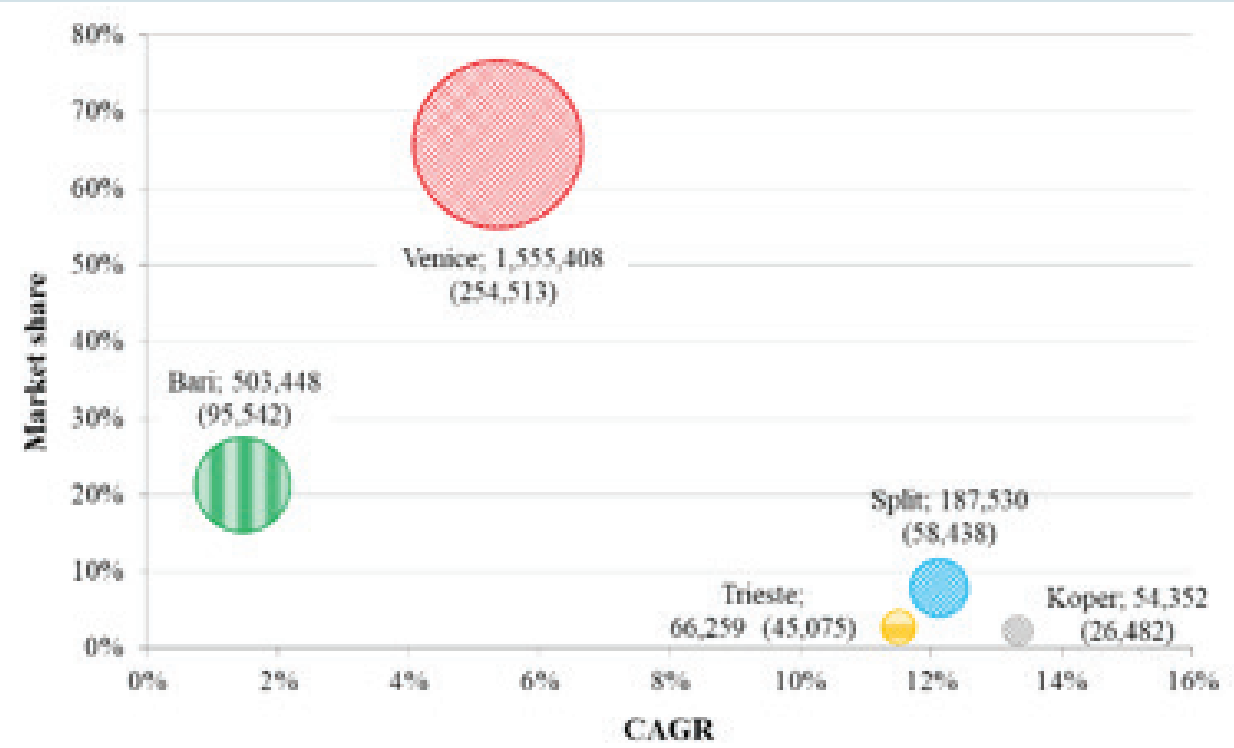

Figure 5 .

CAGR, average market share, average number of passengers and standard deviation (in parenthesis) for the period $2007-2016$. Source: based on internal EA SeaWay data (2014) and (Risposte Turismo, 2017). 
Please note that passengers are usually counted twice in home ports; during embarkation and during disembarkation and that small discrepancies between the two figures are commonplace due to the above mentioned diversification of cruising options.

\subsection{Venice}

Currently, Venice is by far the most visited Adriatic port with around 1.6 million passengers in 2016 (the number drops to approx. 900,000 if double counted passengers that embark and disembark in the port of Venice are not taken into consideration, which would change the picture somewhat). Anyways, it is the most important Adriatic home port and one of the most important Mediterranean home ports with around 700,000 embarkations.

There are two well connected international airports in the vicinity, offering more than 115 regular lines combined. In addition, the Venice's airport Marco Polo is the only airport in the Adriatic offering regular overseas connections.

However, Venice per se is a very visited city in general; the city now receives around 30 million tourists per year, and two or three cruise ships moored at any time can mean an extra 10,000 passengers disgorged into the narrow streets and squares of Venice (Mourby, 2017). So, Venice is facing a similar problem as the Croatian city of Dubrovnik - being overcrowded, especially in the summer months, but for Venice it's not only because of cruise passengers. In addition, the authorities have imposed a limit for the largest cruisers (over 96,000 GT), preventing access to the main cruise terminal through the Giudecca canal due to the damaging effect of the cruisers on the city's architectural supports; large ship motors are damaging the Venice's fragile, salt-corroded foundations. Although the decision was rejected in 2015, the problem persists and a ban on large cruise ships from the Giudecca canal remains a current topic, with almost $99 \%$ of Venetians who voted at an unofficial referendum in June 2017 supporting the ban on these ships and their redirection to the industrial port of Marghera (Giuffrida, 2017).

\subsection{Trieste}

Although the port of Trieste serves as a home port for around half of the cruise tourists visiting the port, its approximately 60,000 cruise tourists are still negligible in comparison to Venice or Bari. This is possible due to adequate terminal capacities (9,900 square meters of outdoor and 7,200 square metres of indoor terminal capacities capable of accommodating two large cruise ships as a home port), well developed hinterland connections (although the connection from the cruise terminal to the highway system is $5 \mathrm{~km}$ away, but the railway station is at a walking distance from the terminal) and the proximity of the national airport.
The Trieste airport has sufficient spare capacity to accommodate additional passengers (although the airport capacity is around 1.5 million passengers (ACW, 2015) it approximately handled only 725,100 passengers (Trieste Airport, 2018) in 2016). In addition, a new intermodal hub will become operational on 19 March 2018, connecting the airport to the national rail network.

\subsection{Bari}

The proximity of an airport (less than $15 \mathrm{~km}$ away) gives Bari an opportunity to become a home port, and more than $27 \%$ of cruise passengers that visited Bari actually boarded the ship in Bari itself. However, back in 2009, this share was around $40 \%$. Although Bari is a strategic port for Costa Cruises, it nevertheless lost one third of cruise passengers in the five-year period from 2012 to 2016.

\subsection{Koper}

The average expenditure per person by port is usually computed from questionnaires, although the quality of these data is frequently limited (Brida and Zapata, 2010). The expenditure assessment for Koper was made in the same way, through questionnaires. According to an estimation cruise ship arrivals with 65,434 passengers generated the revenue of around EUR 5 million for Slovenia in 2013 (Risposte Turismo, 2014). This is without taking into consideration the spending of crew and the broader multiplicative effects. Although number seems high, this is still negligible in comparison to EUR 2.09 billion (RTV SLO, 2014) that foreign tourists spent in Slovenia that same year. Nevertheless, the port of Koper sees the potential of the development of cruise tourism, the construction of a terminal building and consequently the provision of better passenger services.

The trend for cruise passengers visiting Koper is rather indecisive; the power function yields the best estimation and forecasts a slight increase in the coming years, but R2 is barely 0.6. Still, Koper is by far the most important passenger port in Slovenia.

When cruise ships started visiting Koper, Luka Koper, the managing and operating company in the port of Koper, began planning a EUR 10 million worth terminal building. In 2014, they made a less ambitious building plan worth EUR 1.5-2 million, to be constructed very quickly, in time to allow the port of Koper to become a home port in 2015. However, there are still no buildings at the passenger terminal. Once constructed, the structure will include the immigration police, customs, arrival and departure areas, luggage storage, duty free, info point and other shops and services, ensuring the passengers have a comfortable stay (MedCruise, n.d.). In the meantime the community spent 


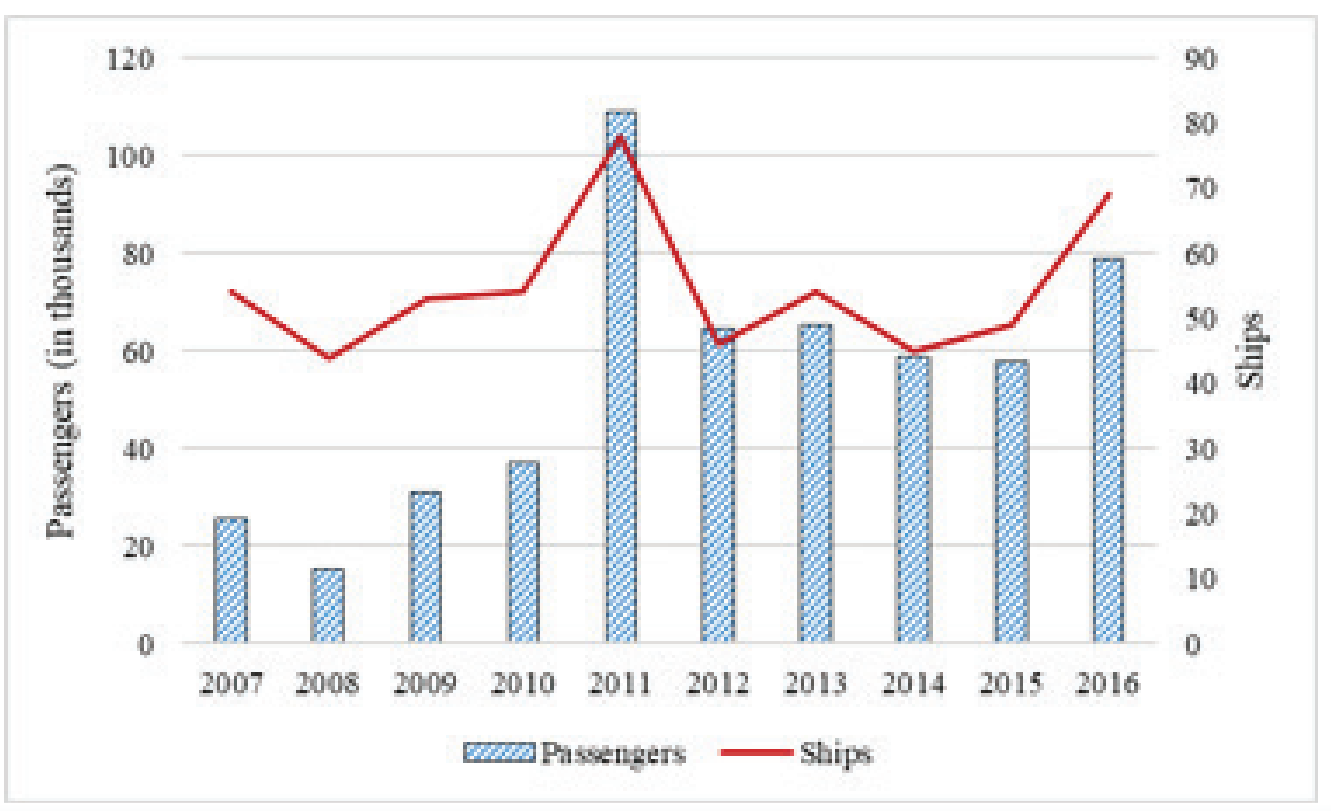

Figure 6.

Number of cruise passengers and cruise ship arrivals to the port of Koper in the period 2007-2016. Source: based on (Luka Koper, 2018).

around EUR 1.95 million on the expansion of the nearby park, beautification of about 700 meters of the promenade and the construction of the elevator bringing cruise passengers directly to the city centre; $85 \%$ of these investments come from nonrefundable European funds.

Although Slovenia has many attractions to offer, the national Ljubljana airport is located $125 \mathrm{~km}$ from Koper, which makes the Trieste airport the closest airport to the port of Koper (less than $70 \mathrm{~km}$ ), but the two, the Trieste airport and the city of Koper, are not well connected.

\subsection{Split}

The port of Split is the largest Croatian passenger port, with around 5 million passengers per year; however, only around 280,000 are cruise passengers, which makes Split the second most important cruise port in Croatia, just behind the ancient city of Dubrovnik. In fact, Split is more often than not merely complementary to Dubrovnik (cruisers rarely call to Split alone).

Cruise traffic has considerably increased in the port of Split over the last decade - the traffic almost tripled between 2007 and 2016 , to reach the already mentioned 280,000 passengers, while in the period 2014-2016 it increased by incredible $51 \%$ - in spite of the lack of dedicated cruise vessel berths and lack of adequate facilities to greet and entertain passengers once they disembark.
The congestion issues in the port of Split in high season were problematic for the arriving cruise ships. Cruise ships were occasionally forced to leave Split due to their inability to berth or provide its passengers the adequate level of comfort and service. However, in 2017 the two outer berths were finished. With the length of $265 \mathrm{~m}$ and width of $30 \mathrm{~m}$, they are capable of simultaneously accommodating two cruise ships of $320 \mathrm{~m}$ and $270 \mathrm{~m}$ respectively. The berths are equipped with border crossing points and sanitary facilities. An access road has been connected to the pier and other supporting infrastructure is present in order to offer high quality service to passengers.

Even without this important in-port acquisition, mathematical models considered the growth of cruise passengers with high coefficient of determination ( $R$ square above 0.81 in all options, besides logarithmic approximation).

The Split airport, only $24 \mathrm{~km}$ from the port, is currently undergoing a major expansion to accommodate increasing traffic, which has almost doubled in the past five years and is expected to reach even higher levels in the future. The ongoing development includes the renovation and expansion of the existing passenger terminal to enhance its capacity to 3.5 million passengers a year, and achieve new levels of safety and service quality (Airport Technology, 2017), i.e. the efficient handling of 2,500 passengers per hour (Bogdan, 2017). Fast rail connection between the Split airport and the port of Split is being considered. 


\section{DISCUSSION}

All current Adriatic home ports have enough terminal capacities with adequate berthing places, well dimensioned terminal buildings with all necessary accompanying services for passengers (check-in desks, waiting areas, luggage storages, souvenir shops, drink machines, transport choices (taxi, bus) etc.), rather good hinterland connections and dense airline connections, as well as a sufficient number of attractions either in the city or in its proximity.

All analysed ports are a part of the TEN-T network; Split is a part of the comprehensive network and all other ports of the core network. This means that they will all benefit from EU financial aids which will be directed into the development of the ports' infrastructure, and the infrastructure connecting the ports with their hinterlands. This could increase their home port potential.

However, although the Adriatic offers many attractions, and regardless of the statement of Rodrigue and Notteboom (2013) that cruise industry sells itineraries and not destinations, it seems that cruise shipping in the Adriatic is still heavily dependent on Venice and Dubrovnik. Both ports struggle with city congestion, and Venice additionally has cruise terminal access issues. If these problems persist, the picture of cruising in the Adriatic could dramatically change; cruising could disappear from the North Adriatic, or other new home ports could emerge in the region. In this event, Trieste is much better positioned than Koper; it is closer to Venice, it has better airline and land connections, as well as passenger terminal facilities. Furthermore, cruise companies tend to be involved in the development, management and operations of the home ports they use (Pallis, Rodrigue and Notteboom, 2014); there is no port authority in Koper, and after the initial enthusiasm over cruise shipping, it is now clear that much higher revenues are generated with cargo handling activities.

Cruise activities are typically seen as income generators for the economy in which they take place. The growth of the industry has socioeconomic benefits for all stakeholders (Pallis, Rodrigue and Notteboom, 2014). These benefits are not unconditional and do not come without certain negative effects, like pollution and congestion. So port authorities, municipalities (local communities) and regions or national governments must be united in decisions on this type of tourism.

According to crew.center (2017) some ships already call to the port of Split several times per season, but only MSC Sinfonia calls on a weekly basis, 20 times per year. This would allow interporting in Split, provided all stakeholders consider this activity profitable and the required investments, mainly into the terminal building with all necessary passenger facilities and adequate parking capacities, are insured. This would be a reasonable upgrade of a EUR 23.3 million investment into much needed outer berths. Interporting would allow passengers to spend time in the city or on the islands before or after their voyages, thus generating additional economic impacts through their tourism expenditures.

Public and private investments have been channelled into many ports where cruise ship callings have increased, to revitalize older port areas encompassing housing, hotels, maritime heritage projects, sports, recreation, tourism and local commerce (Rodrigue and Notteboom, 2013). Non-refundable EU funds are likewise available for cruise port projects.

Since with 6.67 million Europeans cruising in 2016, Europe is the second largest source market worldwide, after the USA, accounting for about $30 \%$ of all cruise passengers worldwide, the exclusively intra-continental links don't necessarily have to be an obstacle (plus non-direct overseas lines available). The majority of European cruise passengers, over $75 \%$, come from 5 countries, namely Germany, the UK \& Ireland (together), Italy, France and Spain. And 3.4 million of European cruise passengers chose the Mediterranean for their destination (CLIA, 2017). While Split airport has direct diversified regular links to these countries, there are no direct flights from Ljubljana to Spain, Ireland or neighbouring Italy. This is another advantage if Split decides to consider the interporting option.

\section{CONCLUSIONS}

The analysis confirmed that at the moment neither of the two ports of interest, namely Koper and Split, has the possibility to become a home port. They can compete with Italian ports in terms of prices (e.g. while in Venice ship call price is from EUR 1,500 on, it is charged EUR 450 in Koper and depending on gross tonnage in Split; similarly in Koper each passenger is charged EUR 4, transit or home port passengers alike, while in Venice this charge is EUR 7.59 per transit passenger and EUR 16.24 to EUR 25.71 per home port passenger (VTP, 2017), (LK, 2017), (SPA, 2016)). However, they lack some other decisive elements, mainly terminal buildings with appropriate passenger services and larger parking areas. Nevertheless, Split is registering a very rapid growth in the number of passengers; in 2016 almost 280 thousand cruise passengers visited Split (187 thousand in average in the analysed period and the trends suggest further growth). In addition, new capacities for receiving cruise ships have been constructed in the meantime, and the current schedule of cruise ship arrivals suggests that the port of Split could become an interport in the near future, but this still requires a number of important in-port investments, mainly the construction of a modern terminal building and the expansion of parking capacities. The construction of a new terminal building has been included in short-term plans and better land access to the port is under consideration.

Koper, on the other hand, recorded a higher compound annual growth than Split in the period under review, but this is 
mainly due to the later entry into the cruise market and very high growth in the early years. Compared to Trieste, Koper is less likely to become a home port if large cruise ships are banned from Venice. Nevertheless, terminal building with adequate services for passengers should be constructed in Koper to give a more pleasant first impression and facilitate the experience of the check procedure for passengers, simultaneously increasing the possibly that more revenue will be yielded from services offered to passengers directly at the terminal. In fact, as Marksel et al. said (2016), a supportive policy framework and products and services of appropriate quality are essential for the stimulation of higher consumption and passenger satisfaction.

\section{REFERENCE}

Airport Technology, 2017. Split International Airport Terminal Rehabilitation and Expansion. Available at: http://www.airport-technology.com/projects/splitinternational-airport-terminal-rehabilitation-and-expansion/, accessed on: Feb 2018.

Bogdan, A., 2017. Novi putnički terminal u Zračnoj luci Split. Građevinar, 69(11), pp. 1041-1050.

BREA, 2015. Econimic contribution of cruise tourism to the destination economies Volume 1. Exton: Business Research \& Economic Advisors.

BREA, 2016. The global economic contribution of cruise tourism 2015. Exton: Business Research \& Economic Advisors.

Brida, J.G. \& Zapata, S., 2010. Cruise tourism: economic, socio-cultural and environmental impacts. International Journal of Leisure and Tourism Marketing, 1(3), p. 205. Available at:

http://dx.doi.org/10.1504/ijltm.2010.029585.

Castillo-Manzano, J.I., Fageda, X. \& Gonzalez-Laxe, F., 2014. An analysis of the determinants of cruise traffic: An empirical application to the Spanish port system. Transportation Research Part E: Logistics and Transportation Review, 66, pp.115125. Available at:

http://dx.doi.org/10.1016/j.tre.2014.03.008.

Celebrity Cruises, 2018. What is an interport sailing? Available at: https://www. celebritycruises.co.uk/faqs/what-is-an-interport-sailing/, accessed on: Feb 2018.

CIN, 2018. Cruise Ship Orderbook. Cruise Industry News. Available at: https://www. cruiseindustrynews.com/cruise-news/cruise-ship-orderbook.html, accessed on: Feb 2018.

CLIA, 2017a. Cruise Industry Overview 2017: State of the Cruise Industry. Washington DC: Cruise Lines International Association.

CLIA, 2017b. Cruise travel report. Washington, DC: Cruise Lines International Association.

CLIA, 2017c. Statistics \& markets 2016 - Europe. Washington: Cruise Lines International Association.

CLIA Europe, 2007. Contribution of cruise tourism to the economies of Europe 2007. Brussels: Cruise Lines International Association.

CLIA Europe, 2015. Contribution of cruise tourism to the economies of Europe 2015. Brussels: Cruise Lines International Association.

Crew.Center, 2017. Split, Croatia Cruise Ship Schedule 2018. Crew.Center. Available at: http://crew-center.com/split-croatia-cruise-ship-schedule-2018, accessed on: Mar 2018.
Dickinson, B. and Vladimir, A., 2008. Selling the sea: An inside look the cruise industry (2nd ed.). New Jersey: Wiley.

Dowling, R. K., 2006. Cruise ship tourism. Oxfordshire \& Cambridge: CAB International.

European Comission, 2009. Tourist facilities in ports - The economic factor. Brussels: European Commission.

Eijgelaar, E., Thaper, C. \& Peeters, P., 2010. Antarctic cruise tourism: the paradoxes of ambassadorship, "last chance tourism" and greenhouse gas emissions. Journal of Sustainable Tourism, 18(3), pp.337-354. Available at: http://dx.doi.org/10.1080/09669581003653534.

FCCA, 2017. Cruise Industry Overview 2017: State of the Cruise Industry. Pembroke Pines: Florida-Caribbean Cruise Association.

Giuffrida, A., 2017. Venice to divert giant cruise ships away from historic centre. The Guardian. Available at: https://www.theguardian.com/world/2017/nov/08/venicecruise-ship-traffic-restricted-amid-concerns-over-damage-to-buildings, accessed on: Nov 2018.

Klein, R.A., 2002. Cruise ship blues: The underside of the cruise ship industry. Gabriola Island: New Society Publishers.

Lakakou, M. B., Pallis, A. A., and Vaggelas, G. K., (2009). Which Home port in Europe: The Cruise industry's selection criteria. Tourismoms: An international Multidisciplinary Journal of Tourism, 4(4), pp. 215-240.

Luka Koper, 2017. Cenik storitev Luke Koper. Koper: Luka Koper.

Luka Koper, 2018. Potniški terminal. Available at:https://luka-kp.si/slo/terminali-191/ single/potniski-terminal-255, accessed on: Feb 2018.

Marksel, M., Tominc, P., and Božičnik, S., 2016. Determinants of cruise passenger's expenditures in the port of call. Management, 21(2), pp. 121-143.

MedCruise, n.d. Koper, a new cruise destination. Available at: http://www.medcruise. com/port/494/koper, accessed on: Feb 2018.

Ma, M.-Z., Fan, H.-M. and Zhang, E.-Y., 2015. Cruise homeport location selection evaluation based on grey-cloud clustering model. Current Issues in Tourism, 21(3), pp.328-354. Available at:

http://dx.doi.org/10.1080/13683500.2015.1083951.

Mourby, A., 2017. Can Venice save itself from its own popularity? CNN Travel. Available at: https://edition.cnn.com/travel/article/venice-too-many-tourists/index. html, accessed on: Feb 2018.

Papadopoulou, G., and Sambracos, E., 2014. The economic signifcance of cruise tourism: An overview in the Mediterranean market. Revista Turismo \& Desenvolvimento, 21/22, pp. 93-94.

Perić, T., 2016. Wastewater pollution from cruise ships in coastal sea area of the Republic of Croatia. Scientific Journal of Maritime Research, 30, pp. 160-164.

Reimer, P., 2012. Passengers can choose where they jump on with interporting. Vancouver Sun. Available at: http://www.vancouversun.com/travel/Passengers+ch oose+where+they+jump+with+interporting/6180587/story.html, accessed on: Feb 2018.

Repositioning Cruises, 2014. Cruise industry. Repositioning Cruises. Available at: http://www.repositioncruises.com/cruise-industry/, accessed on: Feb 2018.

Risposte Turismo, 2014. Ekonomski učinki potniškega terminala koprskega pristanišča na lokalno skupnost in širše slovensko gospodarstvo. Trieste: Risposte Turismo. 
Risposte Turismo, 2017. Adriatic Sea Tourism Report. Venice: Risposte Turismo.

Rodrigue, J.-P., and Notteboom, T., 2012. The geography of cruise shipping: Itineraries, capacity deployment and ports of call. Proceedings of IAME 2012, Taipei.

Rodrigue, J.-P. \& Notteboom, T., 2013. The geography of cruises: Itineraries, not destinations. Applied Geography, 38, pp.31-42. Available at:

http://dx.doi.org/10.1016/j.apgeog.2012.11.011.

Selinsky, D., 2010. Adriatic/Mediterranean Cruises. USA Today Travel Tips. Available at: http://traveltips.usatoday.com/adriatic-mediterranean-cruises-16995.html, accessed on: Feb 2018.

Split Port Authority, 2016. Cjenik (Tarife) naknada uz koje trgovačka društva ovlaštenici koncesija - pružaju usluge korisnicima Luke. Split: Split Port Authority.
Stopford, M., 2009. Maritime economics. London \& New York: Routledge.

Trieste Airport, 2018. Trieste Airport Passenger Numbers. Available at: https://www. triesteairport.net/passenger-statistics.shtml, accessed on: Mar 2018.

Tsamboulas, D., Moraiti, P. and Koulopoulou, G., 2013. How to Forecast Cruise Ship Arrivals for a New Port-of-Call Destination. Transportation Research Record: Journal of the Transportation Research Board, 2330(1), pp.24-30. Available at: http://dx.doi.org/10.3141/2330-04.

VTP, 2017. 2018 General Tariffs. Venice: Venezia Terminal Passeggeri.

Zarei, S., 2015. The key factors in shipping company's port selection for providing their supplies. International Journal of Economics and Management Engineering, 9(4), pp. 1317-1321. 